\title{
Effect of growth stress and interlocked grain on splitting of seven different hybrid clones of Eucalyptus grandis $\times$ Eucalyptus urophylla wood
}

https://doi.org/10.1515/hf-2019-0209

Received August 16, 2019; accepted January 10, 2020

\begin{abstract}
Trees with high levels of growth stress begin to show log end splits (LES) immediately after harvesting, usually reaching its maximum end split in a week, and these tensions also create splits during lumber manufacturing. Interlocked grain is another characteristic that impacts the properties of eucalyptus wood. The aim of this study was to evaluate the effect of growth stress and interlocked grain patterns on log end splitting of seven different hybrid clones of Eucalyptus grandis $\times$ Eucalyptus urophylla planted in Brazil. The growth stress indicator (GSI) was measured in standing trees before harvesting. Splits were measured on logs in three different stages, and interlocked grain from wood blocks was obtained across the center of the cross-section. The results showed that LES occurred as soon as the trees were harvested; however, for better selection of clones, LES should be evaluated after a week of harvesting. There were statistically significant correlations for GSI with LES. Clones that presented higher values of interlocked grain tended to develop lower values of GSI and LES. Using GSI and interlocked grain measurements, it was possible to select the most indicated eucalyptus clones for lumber production.
\end{abstract}

Keywords: clones, eucalyptus, interlocked grain, logs, lumber, residual strain, splits

\footnotetext{
*Corresponding author: Frederico José Nistal França, Department of Sustainable Bioproducts, Mississippi State University, 201 Locksley Way, Starkville, MS 39762, USA, e-mail: fn90@msstate.edu Tâmara Suely Filgueira Amorim França: Department of Sustainable Bioproducts, Mississippi State University, 201 Locksley Way, Starkville, MS 39762, USA

Graziela Baptista Vidaurre: Department of Forestry and Wood Science, Federal University of Espírito Santo, Jerônimo Monteiro, Brazil
}

\section{Introduction}

Eucalyptus sp. is the most planted fast-growing hardwood genus, serving different purposes in the Brazilian industry. Standing out for productivity and adaptability to different environments, eucalyptus wood can reach different segments of the timber industry due to its wood property variation between clones. If the variation in wood properties of eucalyptus clones are known, these clones can be matched to a specific market such as the lumber and furniture industry, pulp and paper industry, or to the production of charcoal for the steel industries (Serpa et al. 2003; Alves et al. 2011; Soares et al. 2015).

Eucalyptus wood is also well known for its defects such as warping and splitting right after harvesting and during lumber processing. In many cases, these defects are due to the growth stress occurring during the growth of the trees (Hardier and Wood 1973; Hardier 1974). Growth stress is a result of tree growth and it is formed by a combination of the formation of a new wood layer during the differentiation process and the weight accumulated in the trunks of trees (Archer 1986; Fournier et al. 1994). Growth stresses are a biomechanical function that reorient the trees to a better position (Kubler 1987; Mattheck and Kubler 1995), are essential for tree survival (Gril et al. 2017), and the distribution of growth stresses around the stem circumference may be asymmetric (Jullien et al. 2013). Growth stresses have a direct influence on the development of crooking and splitting immediately after harvesting (Okuyama et al. 1981; Hillis 1984; Purnell 1988; Tejada et al. 1997; Yang et al. 2001).

It is known that eucalyptus trees, particularly the ones from fast growth plantations, contain internal stresses along the grain that were built during the life of the tree. The release of growth stress in the standing tree generates log end splits (LES), resulting in losses in yield during the breakdown process (Jullien et al.2003). During this process, logs usually split open in the end in one or two directions, and in some cases the end splitting occurs a few hours after bucking, resulting in a greater loss of wood (Skolmen 1963). The selection of trees for timber through the LES method is 
able to increase the yield by reducing end splits on sawn lumber, and also helps to select the best eucalyptus trees for lumber production (Lima et al. 2002, 2004).

Interlocked grain is another characteristic that can impact the yield of eucalyptus wood for lumber production. This characteristic is present in many tropical wood species, and it is formed by the longitudinal direction changing of successive layers of cells during growth (Harris 1989). It is believed that the development of interlocked grain can be evolutionarily advantageous for certain species (Rudinsky and Vite 1959). Interlocked grain in some cases is considered a wood defect as it can cause warp and cracks during the drying process, and twisting and grain-raising during the manufacture of veneer, plywood and lumber (Weddell 1961; Webb 1969). Interlocked grain influences the use and acceptance of planted eucalyptus wood for lumber production (Raymond 2002; Thinley et al. 2005).

It has been proved that interlocked grain benefits the standing tree by improving the water distribution from the roots to the crown (Webb 1969; Détienne 1979), but it also reduces wood stiffness (Marsoem and Kikata 1987; Hernandez and Almeida 2003; Hernandez 2006a,b, 2007; Cabrolier et al. 2009; Brémaud et al. 2010). The influence of interlocked grain strength properties has been recognized, but its influence on log and board splits has not been taken into consideration. Due to the increasing use of eucalyptus wood for lumber production, more information is needed.

Despite what is known regarding eucalyptus wood properties, there is still limited information about growth stress and interlocked grain, and its effect on LES. This information is useful to the lumber industry during selection of clones and trees for lumber production, and it also provides information on the quality of the raw material and possibilities of its end use. Therefore, to increase the yield at sawing, it is important to assess the quality of trees coming from plantations of fast-growing trees.

The goals of the present study were to: (1) measure and quantify the growth stress indicator (GSI) on seven different Eucalyptus grandis Hill ex Maiden $\times$ Eucalyptus urophylla S.T. Blake hybrid clones; (2) characterize and study the different patterns of interlocked grain of each clone; (3) determine the effect of GSI and interlocked grain on LES.

\section{Materials and methods}

Specimens: In October 2000, a total of 20 Eucalyptus grandis $\times$ Eucalyptus urophylla hybrid clones were planted with a $3 \times 3 \mathrm{~m}$ spacing in an experimental plantation located in Alcobaça, Brazil. The trees were neither pruned nor thinned. The experimental area was 10 hectares and its geographical coordinates are $17^{\circ} 33^{\prime} \mathrm{S}$ and $39^{\circ} 22^{\prime}$, with an average altitude of $50 \mathrm{~m}$ and a predominant soil type of podzolic yellow dystrophic.

The climate is hot and rainy tropical, with a predominantly "Af" type (Köppen 1936), with temperatures above $18^{\circ} \mathrm{C}$ in the coldest month. The annual predominant wind direction for this region is northeast, followed by north and south, with an annual average wind speed of $11.9 \mathrm{~km} \mathrm{~h}^{-1}$ with a maximum wind speed of around $50 \mathrm{~km} \mathrm{~h}^{-1}$. The wind intensity for this region is classified as mild (Silva et al. 2002). The average annual precipitation was around $1.378 \mathrm{~mm}$. The variables evaluated in this study are listed in Table 1.

From the 20 hybrid clones, França et al. (2017) identified the best clones that were indicated for lumber production using dendrometric parameters and longitudinal residual deformation. With this information, seven hybrid clones were then selected for this study and a total of 42 trees were obtained from the selected Eucalyptus grandis $\times$ Eucalyptus urophylla hybrid clones (six trees per clone) to evaluate the GSI strain and interlocked grain effect on LES.

The GSI values were determined in the field before trees were harvested. The trees were then cut down and processed into logs. After the breaking down process, three logs were obtained with different lengths, where $\log 1$ and $\log 3$ were $5 \mathrm{~m}$ long, and $\log 2$ was $2 \mathrm{~m}$ in length.

The LES was evaluated in the lower top on $\log 1$ and upper top on $\log 3$, and boards obtained across the center of the cross-section were used to evaluate the interlocked grain. The results for cupping and splitting on boards from log 2 have been described in França et al. (2019). Figure 1 shows the breakdown processes and locations where samples were obtained.

Growth stress indicator: The GSI is a method to measure the magnitude of stress during the growth of trees. The method used in this study was developed by the "Centre de coopération internationale en recherche agronomique pour le développement (Cirad)" described by Fournier et al. (1994). This method is also known as longitudinal residual strain (LRS). This method, expressed in micrometers, has been vastly used in other studies (Fournier et al. 1994; Bailleres et al. 1995; Gerard et al. 1995; Clair et al. 2003, 2013; Alméras et al. 2005; Biechele et al. 2009; Jullien et al. 2013; Amer et al. 2017). However, it does not directly indicate strain but is proportional to it (Fournier et al. 1994).

The GSI values were evaluated in standing and alive trees before harvesting, and the measurements were taken in the vertical direction, following the grain. This variable was measured at the diameter at breast height (DBH) in the north and south directions on the trunk of the trees. Table 2 summarizes the DBH values for all trees tested.

The literature cites different methods to obtain the GSI values, such as procedures that use four to eight points distributed along the

Table 1: List of variables evaluated.

\begin{tabular}{lll}
\hline Variable & Description & Unit \\
\hline GSI & Growth stress indicator & $\mathrm{mm}$ \\
LES & Log end split & $\%$ \\
MAD & Maximum angle deviation & $\circ$ \\
IGI & Interlocked grain index & $\mathrm{mm}$ \\
\hline
\end{tabular}




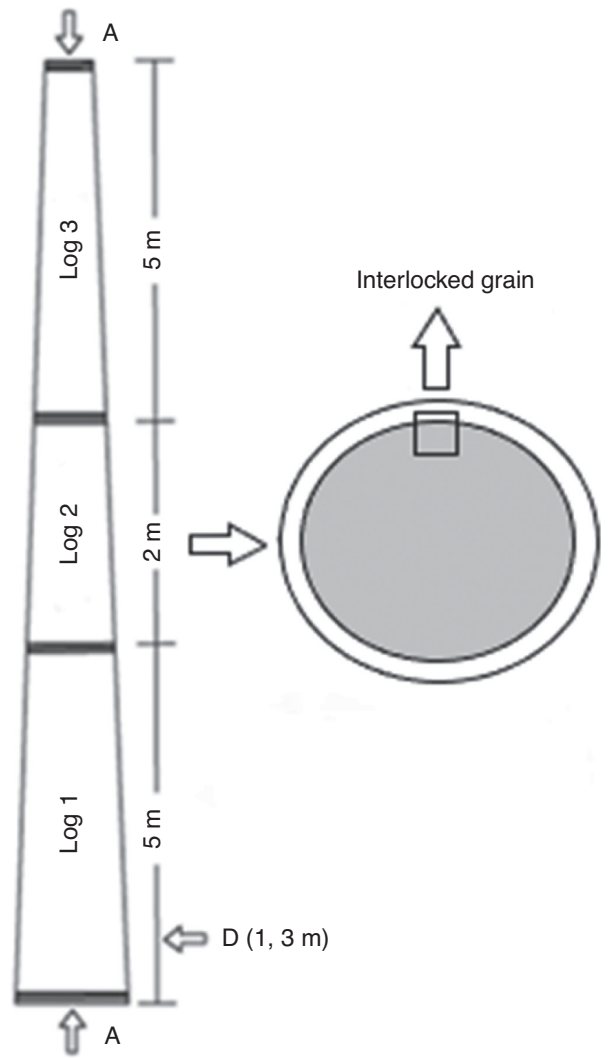

Figure 1: Sampling scheme with arrows indicating the location where samples were obtained in the trunk of 13-year-old Eucalyptus grandis $\times$ Eucalyptus urophylla hybrid clones.

Table 2: Diameter at breast height (DBH) values for all clones tested.

\begin{tabular}{lrrrr}
\hline Clone & Average & Minimum & Maximum & $\begin{array}{r}\text { Coefficient of } \\
\text { variation (\%) }\end{array}$ \\
\hline A & 30.0 & 27.0 & 33.4 & 7.66 \\
B & 33.9 & 33.1 & 35.0 & 2.45 \\
C & 32.5 & 29.6 & 35.5 & 5.91 \\
D & 32.6 & 31.2 & 34.5 & 3.31 \\
E & 37.0 & 32.9 & 42.9 & 9.17 \\
F & 32.9 & 29.9 & 36.0 & 7.64 \\
G & 35.7 & 35.0 & 36.1 & 1.12 \\
\hline
\end{tabular}

trunk to obtain the measurements (Alméras et al. 2005; Jullien and Gril 2008), or two measurements taken from the reaction wood and opposite wood (Jullien et al. 2013). For this study, the chosen method was the one in which measurements were obtained from the north and south positions. To facilitate the GSI measurements, only two positions around the tree circumference were examined corresponding roughly to the main wind direction at the site where tension and opposite wood are expected (Jullien et al. 2013).

The bark was first removed at DBH, and then two pins with a 45-mm distance between pins were introduced to fix the equipment. A hole of $20 \mathrm{~mm}$ was made between the two pins with a drill. When
Table 3: End split length classification.

\begin{tabular}{llr}
\hline Class & End split length & Grade $\left(\mathbf{P}_{\mathbf{i}}\right)$ \\
\hline 1 & Equal to cross-section radius & 1.00 \\
2 & $\begin{array}{l}\text { Less than radius and greater than or equal } \\
\text { to } 3 / 4 \text { of its radius }\end{array}$ & 0.75 \\
3 & $\begin{array}{l}\text { Less than } 3 / 4 \text { but greater than or equal to } \\
1 / 2 \text { radius }\end{array}$ & 0.50 \\
4 & Less than $1 / 2$ but greater than or equal to & 0.25 \\
& $1 / 4$ radius & \\
\hline
\end{tabular}

Source: Wilson (1985).

wood tissue is disrupted by the drill, it releases the strains inside of the tree. The strains were directly recorded by the display, and it corresponds indirectly to the measurements of the growth stresses. Measurements were determined in the absence of wind, which was also recommended by Yang et al. (2005), to avoid bending strain overlapping with the released growth strains.

Log end split: LES was evaluated after trees were harvested and trees were stored in the forest for a week until all LES measurements were obtained. Peripheral shrinkage was not observed. For LES measurements, logs 1 and 3 were used. This study followed the methodology proposed by Wilson (1985) and used by Schacht et al. (1998), Lopes et al. (2004) and Trevisan et al. (2013), which consists of grouping the splits in the cross-section in four different classes based on its length. Table 3 shows the classification of end split length according to Wilson (1985).

The increasing of LES was analyzed by photographing the top of logs in three different periods: right after felling, $24 \mathrm{~h}$ after felling and a week after harvesting. Images of the lower top of $\log 1$ and the upper top of $\log 3$ were analyzed using an image software (ImagePro Plus, 4.5.0.29 for Windows, Media Cybernetics, Silver Spring, MD, USA). The LES value of each tree was determined based on the average of the two logs. After measuring the length of splits on each crosssection, the LES was obtained using Equation 1.

$$
\text { LES }=100\left(\frac{\sum_{\mathrm{i}=1}^{\mathrm{n}} \mathrm{a}_{\mathrm{i}} \cdot \mathrm{P}_{\mathrm{i}}}{\pi \cdot \mathrm{D}}\right)
$$

where LES is the log end split (\%); and $\mathrm{a}_{\mathrm{i}}$ is the length of the split (cm), belonging to $\mathrm{P}_{\mathrm{i}}$ : grade class related to the length of the split $(\mathrm{i}=1, \ldots, 4)$.

Interlocked grain: The interlocked grain can be evaluated through anatomical successive cuts in the tangential-longitudinal plane and/ or radial splitting. For this study, the radial splitting method was used in addition to image analysis by the Image-Pro Plus software. This method was proposed by Weddell (1961) and used by Hernandez and Almeida (2003), which is based on image analysis of the radial division of wood samples. A total of 18 specimens per clone, with dimensions of $50 \mathrm{~mm} \times 50 \mathrm{~mm} \times 50 \mathrm{~mm}$, were sampled to evaluate the interlocked grain index (IGI) and the maximum angle deviation (MAD). Samples were obtained from the wood located under the bark portion of boards cut from the center of the cross-section. Figure 2 shows the scheme for interlocked grain tests.

Each sample was split along the radial plane with a chisel and hammer as shown in Figure 2a. By splitting the cross-section of the 

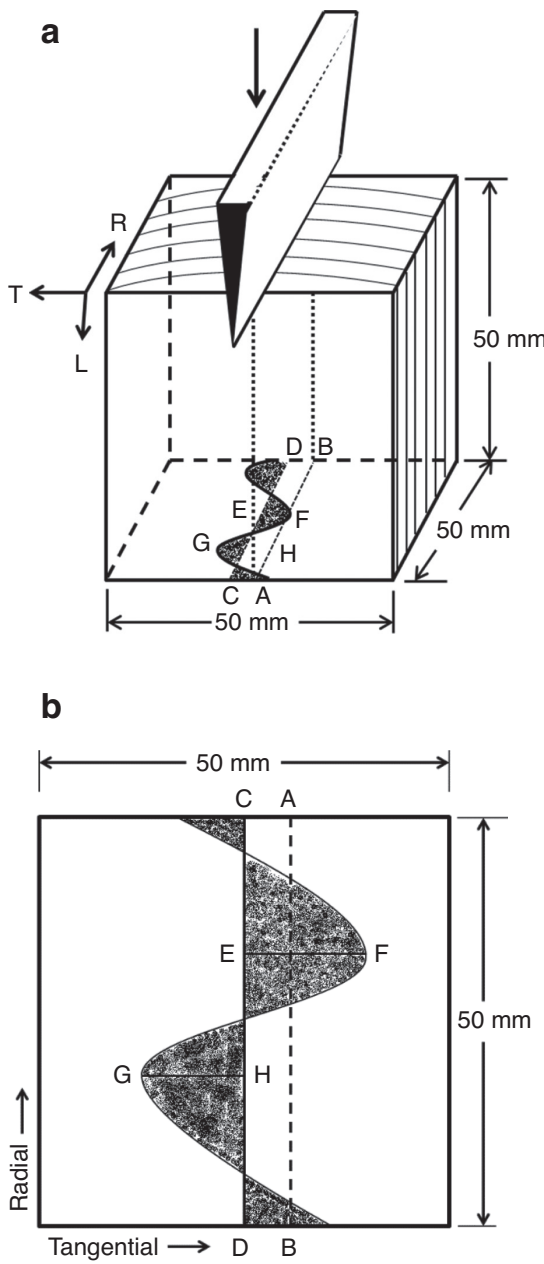
$\mathrm{AB}=$ width of the sample $(\mathrm{mm})$
$\mathrm{CD}=$ straight line parallel to the $\mathrm{AB}$ line to divide the
shadow area of the split into two equal parts
$\mathrm{EF}=$ the ray of deviation of the grain to the right side $(\mathrm{mm})$
$\mathrm{GH}=$ the ray of deviation of the grain to the left side $(\mathrm{mm})$

Figure 2: Scheme to illustrate the interlocked grain test, with maximum angular deviation in degrees and the interlocked grain index in millimeters.

(a) specimens split direction. Source: Adapted from Hernandez and Almeida (2003); (b) interlocked grain measurement patterns.

samples, different interlocked patterns were produced in the crosssections in each specimen. The end split in the cross-sections of each sample was photographed with a digital camera and processed using the Image-Pro Plus software, obtaining the IGI and MAD.

The MAD, in degrees, was estimated as the maximum right spiral angle (angle formed by the line segment EF and sample height) plus the maximum left spiral angle (angle formed by the segment line GH and sample height). Figure 2a shows the protocol of splitting and measurements for estimation of MAD, by using Equation 2 .

$$
\mathrm{MAD}=\operatorname{atan}\left(\frac{\mathrm{EF}}{\mathrm{L}}\right)+\operatorname{atan}\left(\frac{\mathrm{GH}}{\mathrm{L}}\right)
$$

where $\mathrm{MAD}$ is the maximum angle deviation $\left(^{\circ}\right)$; $\mathrm{EF}$ is the ray of deviation in the grain to the right side ( $\mathrm{mm})$; $\mathrm{GH}$ is the ray of deviation of the grain to the left side (mm); and L is the sample height ( $\mathrm{mm}$ ).

The IGI calculation followed the methods listed by Hernandez and Almeida (2003) and Cabrolier et al. (2009). It was determined by dividing the grain area (Figure $2 b$ ) formed by the interlocked grain movement by the length of the sample (distance between points $\mathrm{A}$ and B) using Equation 3.

$$
\mathrm{IGI}=\frac{\mathrm{AS}}{\mathrm{AB}}
$$

where IGI is the interlocked grain index $(\mathrm{mm})$; AS is the grain area under the crosshatched mark $\left(\mathrm{mm}^{2}\right)$; and $\mathrm{AB}$ is the width of the sample $(\mathrm{mm})$.

Statistical analysis: Statistical analysis was performed using a randomized design with a 5\% significance level of confidence. The effect of GSI and interlocked grain measurements in the variables studied on LES were evaluated by analysis of variance (ANOVA). The F test was used $(\mathrm{P}>0.05)$, and the means were compared using Tukey's test. The relationship between variables was evaluated using Pearson's correlation. The statistical analyses were conducted using the software SAS 9.4 (SAS Institute Inc., version 9.4, Cary, NC, USA).

\section{Results and discussion}

Table 4 shows the results for GSI in the north and south directions for all clones tested. There was no statistically significant difference between the GSI mean values for clones within the northern $(0.075 \mathrm{~mm})$ and southern 
Table 4: Average values for growth stress indicator in the north and south direction of 13-year-old Eucalyptus grandis $\times$ Eucalyptus urophylla hybrid clones.

\begin{tabular}{llll}
\hline & \multicolumn{3}{l}{ Growth stress indicator $(\mathrm{mm})$} \\
\cline { 2 - 4 } Clone & North & South & $\begin{array}{l}\text { Average of both } \\
\text { directions }\end{array}$ \\
\hline A & 0.079 & 0.091 & $0.085 \mathrm{~b}$ * \\
& $(21.1)^{\star \star}$ & $(28.7)$ & $(24.9)$ \\
B & 0.116 & 0.098 & $0.107 \mathrm{a}$ \\
& $(21.2)$ & $(32.8)$ & $(27.0)$ \\
C & 0.056 & 0.056 & $0.56 \mathrm{~cd}$ \\
& $(37.0)$ & $(43.6)$ & $(40.3)$ \\
D & 0.047 & 0.037 & $0.042 \mathrm{~d}$ \\
& $(14.7)$ & $(11.7)$ & $(13.2)$ \\
E & 0.050 & 0.042 & $0.046 \mathrm{~d}$ \\
& $(26.6)$ & $(16.7)$ & $(21.7)$ \\
F & 0.070 & 0.072 & $0.071 \mathrm{bc}$ \\
& $(23.4)$ & $(15.3)$ & $(19.34)$ \\
G & 0.110 & 0.068 & $0.089 \mathrm{ab}$ \\
& $(28.9)$ & $(13.1)$ & $(21.0)$ \\
Average & $0.075 \mathrm{~A}$ & $0.066 \mathrm{~A}$ & 0.071 \\
\hline
\end{tabular}

*Average values followed by the same letter do not differ by Tukey's test $(P>0.05)$, where lowercase letters indicate comparisons between clones and capital letters indicate comparisons between the north and south directions. ${ }^{\star \star}$ Coefficient of variation (\%).
(0.066 $\mathrm{mm}$ ) positions, which shows that measurements taken in the north-south direction are not preferred for the reaction of the tree due to factors such as competition for light or wind by the mechanism of growth stress dissymmetry. In this situation, the evaluation of the GSI in only one position, either north or south, would be indicated. Other authors have also reported no significant differences between the results of GSI in different cardinal positions of Eucalyptus grandis $\times$ Eucalyptus urophylla trees at ages between 8 and 15 (Lima et al. 2004; Beltrame et al. 2012).

There was a statistically significant difference for GSI between the seven eucalyptus hybrid clones, where clones D and E had lower GSI mean value $(0.042 \mathrm{~mm}$ and $0.046 \mathrm{~mm}$, respectively), while clone B and $\mathrm{G}$ had higher mean value ( $0.107 \mathrm{~mm}$ and $0.086 \mathrm{~mm}$, respectively). The results found in this research are similar to other studies found for different eucalyptus clones studied by Bailleres et al. (1995), and for 10- and 4-year-old Eucalyptus cloeziana wood studied by Muneri et al. (1999, 2000), respectively.

Table 5 shows the results of LES measurements on logs 1 and 3 into different periods (right after felling, $24 \mathrm{~h}$ after and a week after). The difference in LES among the three periods analyzed on logs is shown in Figure 3. The overall

Table 5: Average values for log end split of 13-year-old Eucalyptus grandis $\times$ Eucalyptus urophylla hybrid clones in different periods of measurement.

\begin{tabular}{|c|c|c|c|c|c|c|c|c|c|}
\hline \multirow[b]{3}{*}{ Clone } & \multicolumn{9}{|c|}{ Log end split (\%) } \\
\hline & \multicolumn{3}{|c|}{ After felling } & \multicolumn{3}{|c|}{ After $24 \mathrm{~h}$} & \multicolumn{3}{|c|}{ After 1 week } \\
\hline & $\log 1$ & $\log 3$ & Ave. & $\log 1$ & $\log 3$ & Ave. & $\log 1$ & $\log 3$ & Ave. \\
\hline A & $\begin{array}{l}0.08 \\
(62.2)\end{array}$ & $\begin{array}{l}0.24 \\
(50.68)\end{array}$ & $\begin{array}{l}0.116 a^{\star} \\
(44.91)^{\star \star}\end{array}$ & $\begin{array}{l}0.26 \\
(41.3)\end{array}$ & $\begin{array}{l}0.46 \\
(23.81)\end{array}$ & $\begin{array}{l}0.36 \mathrm{a} \\
(25.35)\end{array}$ & $\begin{array}{l}0.42 \\
(23.2)\end{array}$ & $\begin{array}{l}0.66 \\
(9.9)\end{array}$ & $\begin{array}{l}0.54 \mathrm{a} \\
(11.86)\end{array}$ \\
\hline B & $\begin{array}{l}0.19 \\
(42.2)\end{array}$ & $\begin{array}{l}0.12 \\
(48.79)\end{array}$ & $\begin{array}{l}0.151 \mathrm{a} \\
(31.55)\end{array}$ & $\begin{array}{l}0.38 \\
(24.6)\end{array}$ & $\begin{array}{l}0.28 \\
(40.87)\end{array}$ & $\begin{array}{l}0.33 \mathrm{ab} \\
(27.82)\end{array}$ & $\begin{array}{l}0.51 \\
(32.5)\end{array}$ & $\begin{array}{l}0.38 \\
(30.3)\end{array}$ & $\begin{array}{l}0.45 \mathrm{~b} \\
(29.00)\end{array}$ \\
\hline $\mathrm{C}$ & $\begin{array}{l}0.07 \\
(73.2)\end{array}$ & $\begin{array}{l}0.30 \\
(42.88)\end{array}$ & $\begin{array}{l}0.17 a \\
(43.04)\end{array}$ & $\begin{array}{l}0.20 \\
(44.9)\end{array}$ & $\begin{array}{l}0.39 \\
(19.76)\end{array}$ & $\begin{array}{l}0.30 \mathrm{ab} \\
(27.00)\end{array}$ & $\begin{array}{l}0.38 \\
(17.0)\end{array}$ & $\begin{array}{l}0.52 \\
(6.2)\end{array}$ & $\begin{array}{l}0.45 b \\
(11.56)\end{array}$ \\
\hline D & $\begin{array}{l}0.02 \\
(45.3)\end{array}$ & $\begin{array}{l}0.06 \\
(25.60)\end{array}$ & $\begin{array}{l}0.04 \mathrm{~b} \\
(27.18)\end{array}$ & $\begin{array}{l}0.15 \\
(33.9)\end{array}$ & $\begin{array}{l}0.17 \\
(34.14)\end{array}$ & $\begin{array}{l}0.16 \mathrm{c} \\
(28.11)\end{array}$ & $\begin{array}{l}0.24 \\
(31.1)\end{array}$ & $\begin{array}{l}0.281 \\
(10.2)\end{array}$ & $\begin{array}{l}0.26 \mathrm{c} \\
(13.45)\end{array}$ \\
\hline $\mathrm{E}$ & $\begin{array}{l}0.01 \\
(121.5)\end{array}$ & $\begin{array}{l}0.07 \\
(36.01)\end{array}$ & $\begin{array}{l}0.04 \mathrm{~b} \\
(48.53)\end{array}$ & $\begin{array}{l}0.15 \\
(30.2)\end{array}$ & $\begin{array}{l}0.19 \\
(34.57)\end{array}$ & $\begin{array}{l}0.17 \mathrm{c} \\
(31.62)\end{array}$ & $\begin{array}{l}0.29 \\
(17.7)\end{array}$ & $\begin{array}{l}0.26 \\
(18.6)\end{array}$ & $\begin{array}{l}0.27 \mathrm{c} \\
(8.58)\end{array}$ \\
\hline $\mathrm{F}$ & $\begin{array}{l}0.05 \\
(31.9)\end{array}$ & $\begin{array}{l}0.09 \\
(30.73)\end{array}$ & $\begin{array}{l}0.07 \text { b } \\
(20.57)\end{array}$ & $\begin{array}{l}0.23 \\
(19.0)\end{array}$ & $\begin{array}{l}0.29 \\
(22.15)\end{array}$ & $\begin{array}{l}0.26 \mathrm{~b} \\
(17.18)\end{array}$ & $\begin{array}{l}0.51 \\
(13.9)\end{array}$ & $\begin{array}{l}0.47 \\
(7.1)\end{array}$ & $\begin{array}{l}0.49 a b \\
(7.50)\end{array}$ \\
\hline G & $\begin{array}{l}0.11 \\
(18.5)\end{array}$ & $\begin{array}{l}0.20 \\
(42.15)\end{array}$ & $\begin{array}{l}0.15 \mathrm{a} \\
(29.33)\end{array}$ & $\begin{array}{l}0.24 \\
(39.4)\end{array}$ & $\begin{array}{l}0.34 \\
(29.81)\end{array}$ & $\begin{array}{l}0.29 \mathrm{ab} \\
(21.85)\end{array}$ & $\begin{array}{l}0.57 \\
(16.9)\end{array}$ & $\begin{array}{l}0.49 \\
(28.4)\end{array}$ & $\begin{array}{l}0.53 \mathrm{ab} \\
(19.40)\end{array}$ \\
\hline Ave. & $0.08 \mathrm{~A}$ & $0.15 \mathrm{~A}$ & 0.11 & $0.23 \mathrm{~A}$ & $0.30 \mathrm{~A}$ & 0.27 & $0.42 \mathrm{~A}$ & $0.44 \mathrm{~A}$ & 0.43 \\
\hline
\end{tabular}

*Average values followed by the same letter do not differ by Tukey's test $(P>0.05)$, where lowercase letters indicate comparisons between clones and capital letters indicate comparisons between LES average values. ${ }^{\star *}$ Coefficient of variation (\%). 
a

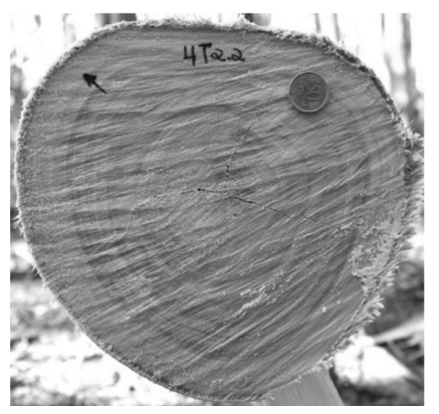

b

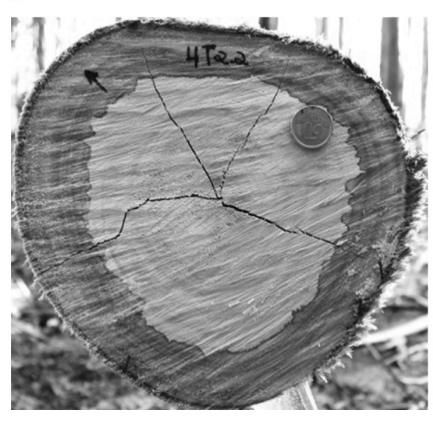

c

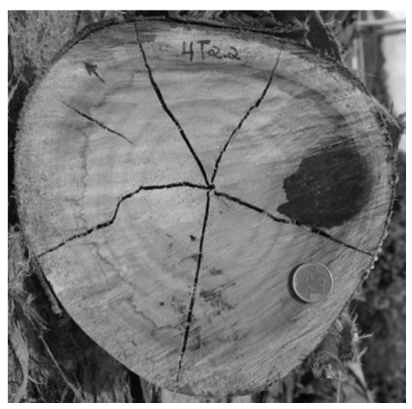

Figure 3: Log end split appearance in three different moments.

(a) right after harvesting; (b) $24 \mathrm{~h}$ after harvesting; (c) 7 days after harvesting.

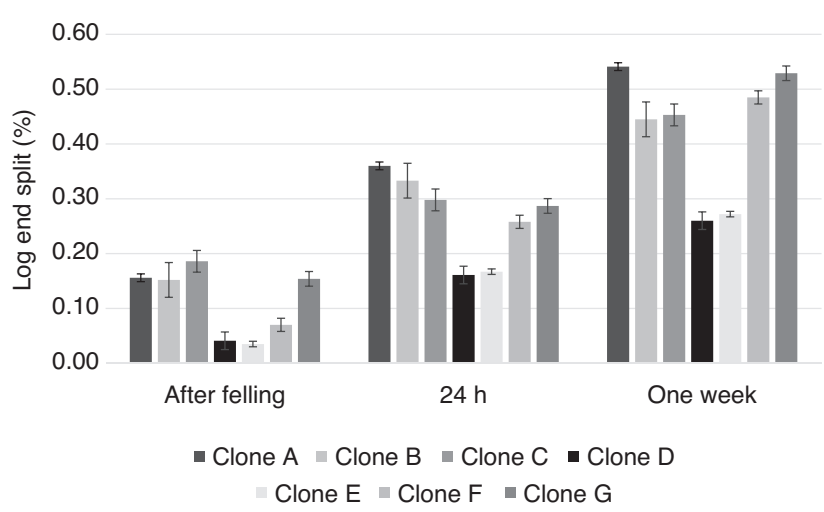

Figure 4: Log end split per clone evaluated at different moments.

Table 6: Interlock grain results of 13-year-old Eucalyptus grandis $\times$ Eucalyptus urophylla hybrid clones.

\begin{tabular}{lll}
\hline Clone & $\begin{array}{l}\text { Maximum angular } \\
\text { deviation }\left({ }^{\circ}\right)\end{array}$ & $\begin{array}{l}\text { Interlocked grain } \\
\text { index }(\mathrm{mm})\end{array}$ \\
\hline $\mathrm{A}$ & $12.0 \mathrm{~cd}^{\star}$ & $1.0 \mathrm{~cd}$ \\
$(17.04)^{\star \star}$ & $(25.52)$ \\
$\mathrm{B}$ & $11.9 \mathrm{~cd}$ & $1.2 \mathrm{c}$ \\
$(13.96)$ & $(19.93)$ \\
$\mathrm{C}$ & $6.9 \mathrm{de}$ & $0.5 \mathrm{~d}$ \\
& $(20.77)$ & $(30.02)$ \\
D & $21.5 \mathrm{~b}$ & $2.0 \mathrm{~b}$ \\
& $(6.87)$ & $(18.34)$ \\
E & $29.8 \mathrm{a}$ & $2.9 \mathrm{a}$ \\
& $(6.69)$ & $(29.57)$ \\
F & $12.9 \mathrm{c}$ & $0.9 \mathrm{~cd}$ \\
& $(21.57)$ & $(34.52)$ \\
G & $6.7 \mathrm{e}$ & $0.6 \mathrm{~d}$ \\
& $(14.28)$ & $(24.51)$ \\
Average & 14.6 & 1.3 \\
\hline
\end{tabular}

*Average values followed by the same letter do not differ by Tukey's test $(P>0.05)$. ${ }^{* \star}$ Coefficient of variation (\%). mean values of LES for the clones tested after cutting, after $24 \mathrm{~h}$ after cutting and after 1 week were $0.11 \%, 0.27 \%$ and $0.43 \%$, respectively. Clones D and E exhibited statistically lower LES values in all three moments evaluated compared to the other clones. Results found in this research are in accordance with other studies, where values between $0.15 \%$ and $3.5 \%$ were obtained in assessments between the $4^{\text {th }}$ and $6^{\text {th }}$ day after cutting in E. urophylla and E. grandis clones with ages between 9 and 29 years old (Schacht et al. 1998; Lopes et al. 2004; Trevisan et al. 2013).

The largest variation in the increasing of LES occurred in the first $24 \mathrm{~h}$ after felling, with an average increase of $134 \%$, while the average increase in LES between $24 \mathrm{~h}$ and 1 week after was $60 \%$ (Figure 4). This variation is probably due to the higher growth stresses relief rate in the first $24 \mathrm{~h}$ after harvesting. Similar results were reported for $E$. grandis and Eucalyptus camaldulensis Dehnh. studied by Amer et al. (2017). Clones D and E had higher increase in LES mean values between after felling and $24 \mathrm{~h}$ (293\% and $377 \%$, respectively), while Clone F showed the highest LES mean values between measurements taken between $24 \mathrm{~h}$ and 1 week later (88\%).

Overall, LES mean values of $\log 3$ were higher compared to $\log 1$ for the three periods tested, but no statistical difference between logs was found. These results are similar to the ones found for $E$. grandis trees aged 8 and 21 years old reported by Santos (2002) and Lima et al. (2007), respectively.

The overall mean values for MAD and IGI were $14.6^{\circ}$ and $1.3 \mathrm{~mm}$, respectively (Table 6). There was statistically significant difference among clones for the two methodologies tested (MAD and IGI), and several patterns of interlocked grain were generated in cross-sections of tested clones (Figure 5). Clone E showed statistically higher values for MAD and IGI (29.8 ${ }^{\circ}$, and $2.9 \mathrm{~mm}$, respectively), 


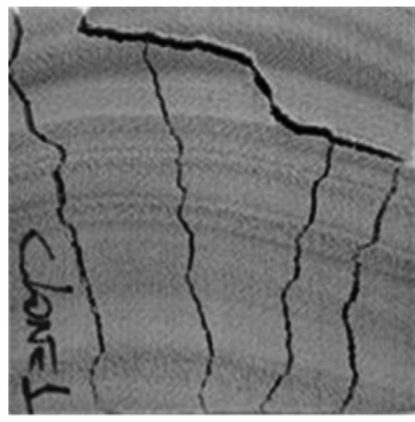

Clone A

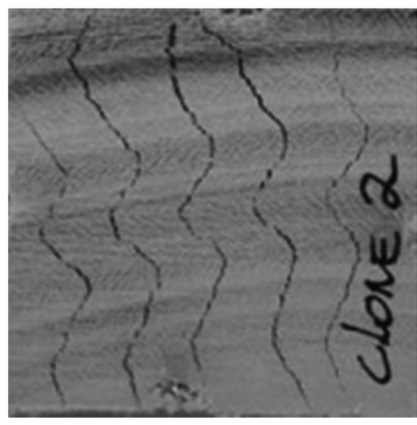

Clone B

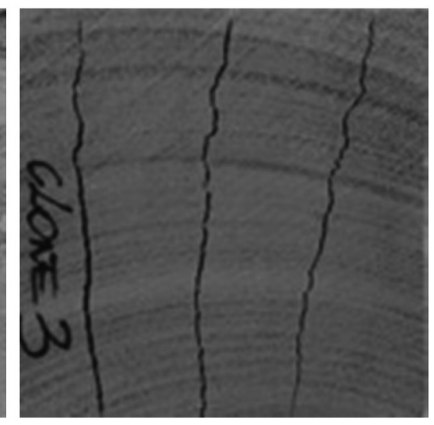

Clone C

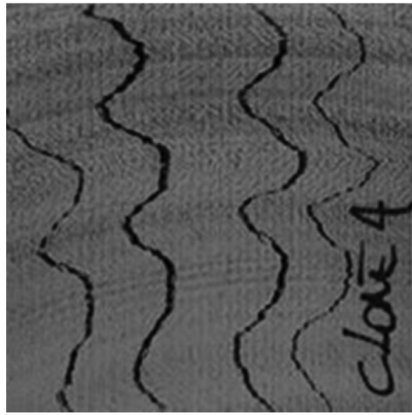

Clone D

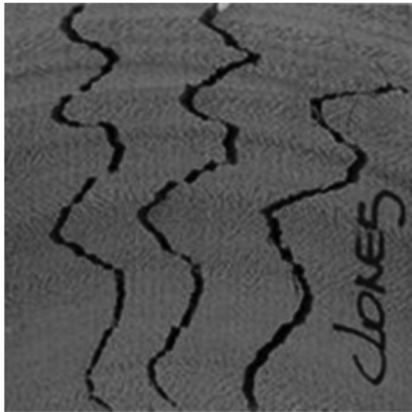

Clone E

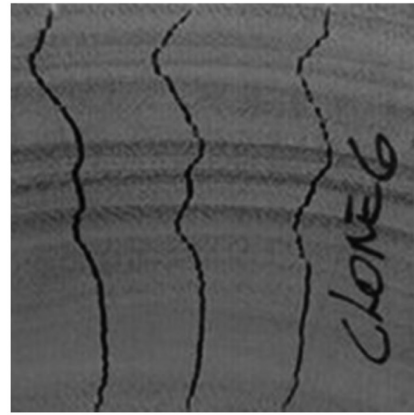

Clone F

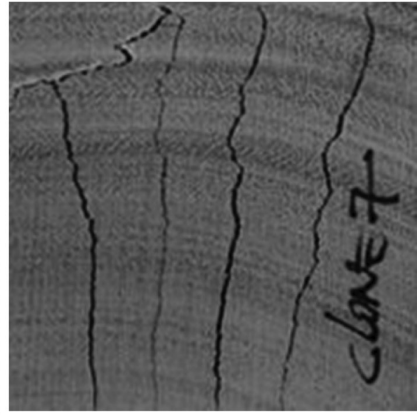

Clone G

Figure 5: Interlocked grain patterns found radial splitting on each clone.

followed by the clone $\mathrm{D}\left(21.5^{\circ}\right.$ and $2.0 \mathrm{~mm}$, respectively). Clone $\mathrm{G}$ and $\mathrm{C}$ showed statistically lower values for MAD $\left(6.7^{\circ}\right.$ and $6.9^{\circ}$, respectively) and IGI mean values $(0.6 \mathrm{~mm}$ and $0.5 \mathrm{~mm}$, respectively). Similar results were reported by Cabrolier et al. (2009) and Bossu et al. (2018).

There was a significant correlation of determination of 0.927 between the two methodologies used to evaluate interlocked grain (MAD and IGI), showing that both methods are suitable and appropriate for evaluation. Cabrolier et al. (2009) obtained $\mathrm{r}^{2}=0.81$ studying native species from French Guiana, and Hernandez and Almeida (2003) obtained $\mathrm{r}^{2}=0.836$ studying tropical species in the Peruvian Amazon.

Relatively few data are available on the interlocked grain measurements of wood species and no studies have been conducted on the evaluation of interlocked grain of eucalyptus wood to compare the results of this study. Studies showed MAD values between $6^{\circ}$ and $16^{\circ}$ and IGI ranging from $0.3 \mathrm{~mm}$ to $2.8 \mathrm{~mm}$ for Aspidosperma macrocarpon, Clarisia racemosa, Tabebuia spp., Dipterix odorata and Bagassa guianensis, all tropical species (Hernandez and Almeida 2003; Cabrolier et al. 2009; Bossu et al. 2018).

The GSI showed positive correlation with LES (Figure 6). The correlation was significant only for the evaluation at 1 week after harvesting $(r=0.447)$, due to the greater relief of growth stresses in the form of splits after a

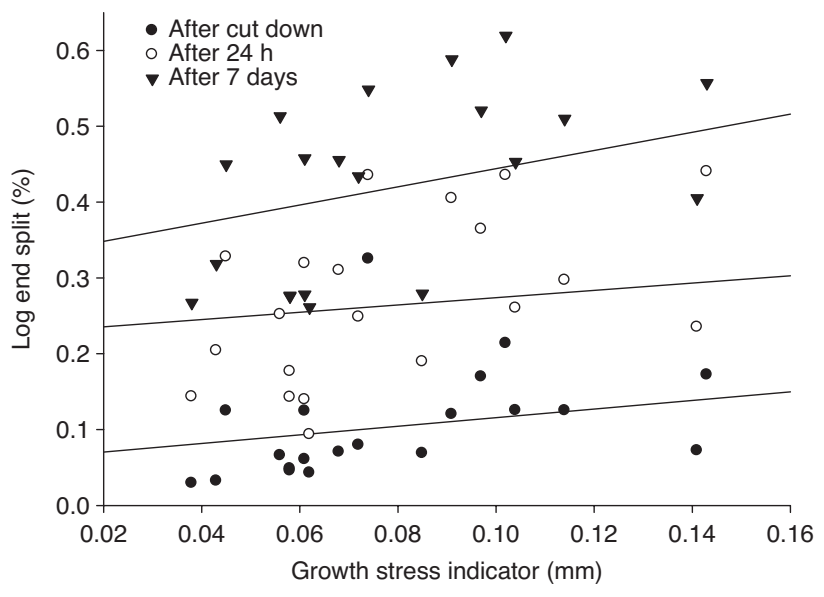

Figure 6: Relationship between the growth stress indicator with log end split of 13-year-old Eucalypts grandis $\times$ Eucalyptus urophylla hybrid clones.

week. Similar results were found in studies that reported the same relationship in eucalyptus logs and for other species (Aguiar and Jankowsky 1986; Lima et al. 2004; Trevisan et al. 2013).

Figure 7 shows correlations for MAD and IGI with LES. Significant negative correlations were found for MAD $(r=0.579 ; P<0.01)$ and IGI $(r=0.545 ; P=0.011)$ in LES measured right after felling of trees. After $24 \mathrm{~h}$, the correlations increased to $0.599(\mathrm{P}<0.01)$ and 0.570 

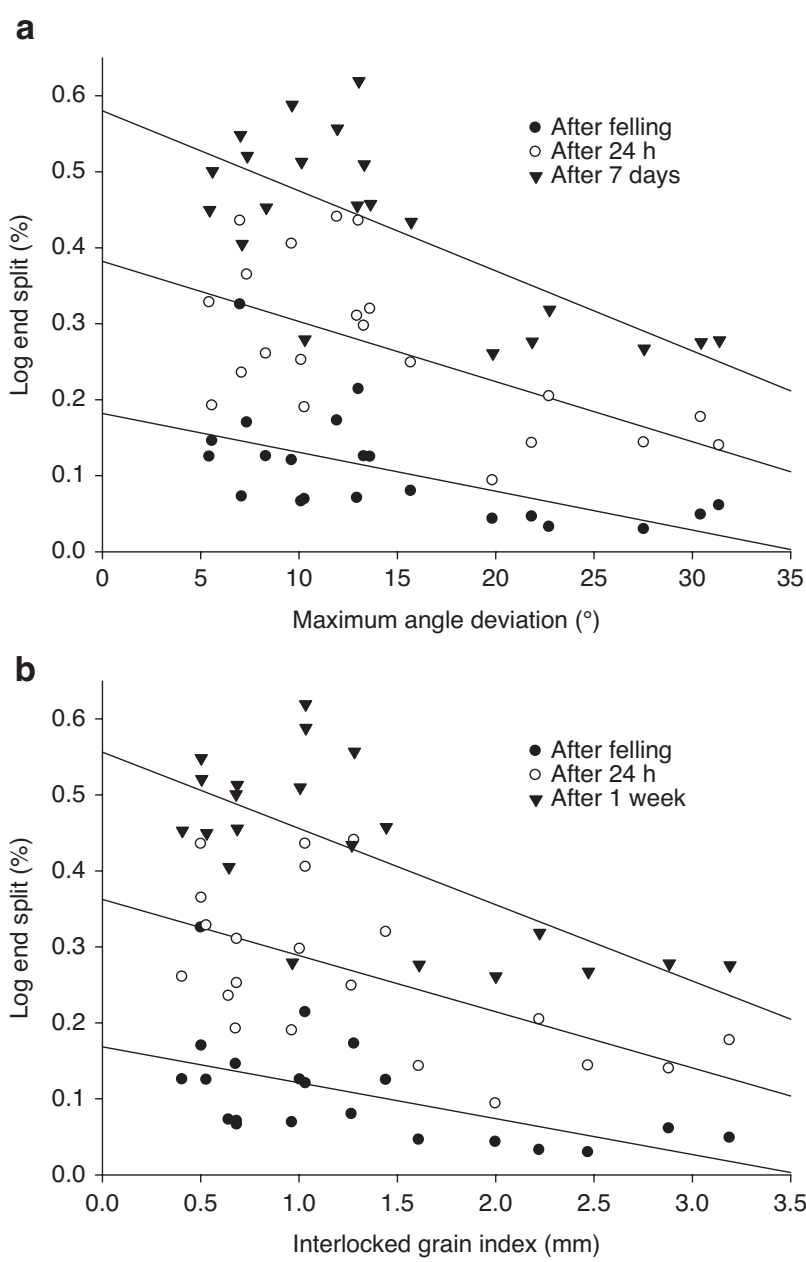

Figure 7: Relationship between log end split with interlocked grain measurements.

(a) maximum angular deviation; and (b) interlocked grain index of 13-year-old Eucalypts grandis $\times$ Eucalyptus urophylla hybrid clones.

$(\mathrm{P}<0.01)$ for MAD and IGI, respectively. After 7 days of harvesting, the correlations remained significant and equal to $0.715(\mathrm{P}<0.01)$ for $\mathrm{MAD}$ and $0.695(\mathrm{P}<0.01)$ for IGI, showing that the releasing of tensions over time increased the correlation between the interlocked grain rates and LES.

Figure 8 shows a negative correlation of $0.513(\mathrm{P}<0.02)$ between interlocked grain and GSI. Due to the high correlation between MAD and IGI, only one parameter (MAD) was used to evaluate this correlation. In this study, clones $\mathrm{D}$ and $\mathrm{E}$ presented higher levels of interlocked grain and lower values of GSI and LES. These findings confirm that clones with higher interlocked grain values presented lower GSI and LES values.

It is possible that the higher levels of interlocked grain in certain clones was developed after the tree became dominant. Bossu et al. (2018) stated that this behavior also

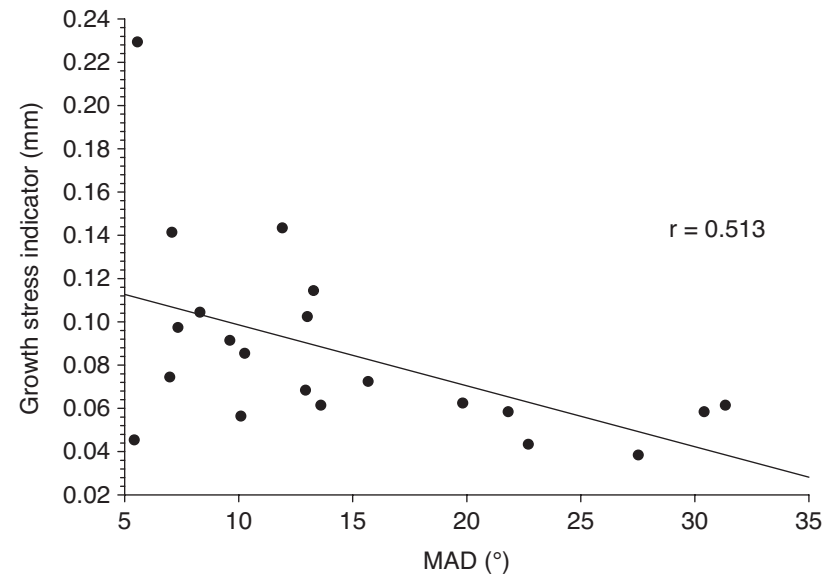

Figure 8: Relationship between MAD and LRS of 13-year-old Eucalypts grandis $\times$ Eucalyptus urophylla hybrid clones.

occurs in trees from dense tropical forests, where species develop different strategies of growth, allowing them to reach a dominant position within the canopy and to guarantee trunk weight-bearing capacities. Changes in wood during the development of trees allow them to adapt their growth rate and to reduce the risk of splitting by improving the resistance to torsion.

\section{Conclusions}

- LES varied with height in the trees, with an increase in splits in the bottom-up direction.

- The selection of clones through LES should be done after 7 days of harvesting when all tension have been released.

- Clones with higher levels of interlocked grain showed lower values of GSI and LES.

- Interlocked grain can be considered useful during the selection of eucalyptus trees for lumber production.

- MAD is more recommended to evaluate the interlocked grain because the measurement is easier and faster compared to the IGI method.

Author contributions: All the authors have accepted responsibility for the entire content of this submitted manuscript and approved submission.

Research funding: The authors are grateful for the financial support of Fundação de Amparo à Pesquisa e Inovação do Espírito Santo (FAPES; Vitória, Brazil), and FIBRIA S.A. (Aracruz, Brazil) for providing the wood samples for the study. This material is held at the Mississippi State University Forest and Wildlife Research Centre under the manuscript designation SB952. 
Employment or leadership: None declared. Honorarium: None declared.

\section{References}

Aguiar, O.J.R., Jankowsky, I.P. (1986) Prevention and control of end splits in logs of Eucalyptus grandis Hill Ex Maiden. IPEF 33:39-46. In Portuguese with abstract in English.

Alméras, T., Thibaut, A., Gril, J. (2005) Effect of circumferential heterogeneity of wood maturation strain, modulus of elasticity and radial growth on the regulation of stem orientation in trees. Trees 19:457-467.

Alves, I.C.N., Gomide, J.L., Colodette, J.L., Silva, H.D. (2011) Caracterização tecnológica da madeira de Eucalyptus benthamii para produção de celulose kraft [Technological characterization of Eucalyptus benthamii wood for kraft pulp production]. Cienc. Florest. 21:167-174. In Portuguese with abstract in English.

Amer, M., Kabouchi, B., Rahouti, M., Famiri, A., Fidah, A. (2017) Determination of growth stresses indicator, moisture profiles and basic density of clonal eucalyptus wood. J. Ind. Acad. Wood Sci. 14:91-98.

Archer, R.R. (1986) Growth stresses and strains in trees. Springer, Berlin. pp. 1-249.

Bailleres, H., Chanson, B., Fournier, M., Tollier, M.T., Monties, B. (1995) Structure, composition chimique et retraits de maturation du bois chez les clones d'Eucalyptus [Wood structure, chemical composition and growth strains in Eucalyptus clones]. Ann. Sci. For. 52:157-172. In French with abstract in English.

Beltrame, R., Lozarotto, M., Haselein, C.R., Santini, E.J., Schneider, P.R., Aguiar, A.M. (2012) Determinação das deformações residuais longitudinais decorrentes das tensões de crescimento em Eucalyptus spp. [Determination of longitudinal residual strain due to growth stress in Eucalyptus spp.]. Cienc. Florest. 22:343-351. In Portuguese with abstract in English.

Biechele, T., Nutto, L., Becker, G. (2009) Growth strain in Eucalyptus niters at different stages of development. Silva Fenn. 43:669-679.

Bossu, J., Lehnebach, R., Corn, S., Regazzi, A., Beauchêne, J., Clair, B. (2018) Interlocked grain and density patterns in Bagassa guianensis: changes with ontogeny and mechanical consequences for trees. Trees 32:1643-1655.

Brémaud, I., Cabrolier, P., Gril, J., Clair, B., Gérard, J., Minato, K., Thibaut, B. (2010) Identification of anisotropic vibrational properties of Padauk wood with interlocked grain. Wood Sci. Technol. 44:355-367.

Cabrolier, P., Beauchêne, J., Thibaut, B. (2009) Is interlocked grain an adaptive trait for tropical tree species in rainforest? In: 6th Plant Biomechanics Conference, November 16-21, 2009. Cayenne, French Guyana, France. pp. 279-284.

Clair, B., Ruelle, J., Thibaut, B. (2003) Relationship between growth stress, mechano-physical properties and proportion of fibre with gelatinous layer in Chestnut (Castanea sativa Mill.). Holzforschung 57:189-195.

Clair, B., Alteyrac, J., Gronvold, A., Espejo, J., Chanson, B., Alméras, T. (2013) Patterns of longitudinal and tangential maturation stresses in Eucalyptus nitens plantation trees. Ann. For. Sci. 70:801-811.

Détienne, P. (1979) Contrefil à rythme annuel dans les faro Daniellia sp. Bois. For. Trop. 183:67-71.
Fournier, M., Chanson, B., Thibaut, B., Guitard, D. (1994) Mesures des déformations résiduelles de croissance à la surface des arbres, en relation avec leur morphologie. Observations sur différentes espèces [Measurements of residual growth strains at the stem surface: observations on different species]. Ann. Sci. For. 51:249-266. In French with abstract in English.

França, F.J.N., Viduarre, G.B., Nutto, L., Abad, J.I.M., Batista, D.C., Moulin, J.C. (2017) Relation between dendrometric variables and growth stress in eucalyptus. Floresta Ambient. 24:1-6.

França, J.F.N., Maciel, A.P.V., França, T.S.F.A., Silva, J.G.M., Batista, D.C. (2019) Air-drying of seven clones of Eucalyptus grandis $\times$ Eucalyptus urophylla wood. BioResources 14: 6591-6607.

Gerard, J., Bailleres, H., Fournier, M., Thibaut, B. (1995) Wood quality in plantation Eucalyptus - a study of variation in three reference properties. Bois. For. Trop. 245:101-110. In French with abstract in English.

Gril, J., Jullien, D., Bardet, S., Yamamoto, H. (2017) Tree growth stress and related problems. J. Wood. Sci. 63:411-432.

Hardier, A.D.K. (1974) Defects in the wood of fast-grown Eucalyptus grandis in Zambia. Commonw. For. Rev. 53:310-317.

Hardier, A.D.K., Wood, A.A. (1973) Eucalyptus grandis timber from plantations in Zambia Commonw. For. Rev. 52:153-159.

Harris, J.M. Spiral Grain and Wave Phenomena in Wood Formation. Springer, Heidelberg, 1989. p. 215.

Hernandez, R. (2006a) Moisture sorption properties of hardwoods as affected by their extraneous substances, wood density and interlocked grain. Wood Fiber Sci. 39:132-145.

Hernandez, R. (2006b) Swelling properties of hardwoods as affected by their extraneous substances, wood density, and interlocked grain. Wood Fiber Sci. 39:146-158.

Hernandez, R. (2007) Influence of accessory substances, wood density and interlocked grain on the compressive properties of hardwoods. Wood Sci Technol. 41:249-265.

Hernandez, R., Almeida, G. (2003) Effects of wood density and interlocked grain on the shear strength of three Amazonian tropical hardwoods. Wood Fiber Sci. 35:154-166.

Hillis, W.H. (1984) Wood quality and utilization. In: Eucalyptus for Wood Production. Eds. Hillis, W.H., Brown, A.G. CSIRO, Melbourne. p. 434.

Image-Pro Plus. (2000) Version 4.5.0.29. Media Cybernetics, Inc., Rockville, MD, USA, 2000.

Jullien, D., Gril, J. (2008) Growth strain assessment at the periphery of small-diameter trees using the two-grooves method: influence of operating parameters estimated by numerical simulations. Wood Sci. Technol. 42:551-565.

Jullien, D., Laghdir, A., Gril, J. (2003) Modelling log-end cracks due to growth stresses: calculation of the elastic energy release rate. Holzforschung 57:407-414.

Jullien, D., Widmann, R., Loup, C., Thibaut, B. (2013) Relationship between tree morphology and growth stress in mature European beech stands. Ann. For. Sci. 70:133-142.

Köppen, W. (1936) Das geographische System der Klimate. In: Handbuch der Klimato - logie. Eds. Köppen, W., Geiger, R. Gebrüder Borntraeger, Berlin. p. 1- 44.

Kubler, H. (1987) Growth stresses in trees and related wood properties. For. Abstr. 48:131-189.

Lima, I.L., Garcia, J.N., Piedade, S.M.S. (2002) Rachaduras de extremidades de tora e suas implicações nas rachaduras da madeira serrada [Log end splitting and their implications on 
lumber end splitting]. Sci. For. 61:13-24. In Portuguese with abstract in English.

Lima, J.T., Trugilho, P.F., Rosado, S.C.S., Cruz, C.R. (2004) Deformações residuais longitudinais decorrentes de tensões de crescimento em eucaliptos e suas associações com outras propriedades [Longitudinal residual strains resulted from growth stresses in eucalypts and their association with other properties]. Rev. Árvore 28:107-116. In Portuguese with abstract in English.

Lima, I.L., Garcia, J.N., Stape, J.L. (2007) Influência do desbaste e da fertilização no deslocamento da medula erachaduras de extremidade de tora de Eucalyptus grandis Hill ex-Maiden [Effect of thinning and fertilization on Eucalyptus grandis Hill Ex-Maiden pith displacement and log end splittlng]. Cerne 13:170-177. In Portuguese with abstract in English.

Lopes, M.C., Haselein, C.R., Santini, E.J., Longhi, S.J., Rosso, S., Fernandes, D.L.G., Menezes, L.F. (2004) Agrupamento de árvores matrizes de Eucalyptus grandis em função das variáveis dendrométricas e das caracteristicas tecnológicas da madeira [Grouping of Eucalyptus grandis selected trees in function of the dendrometric variables and the technological characteristics of wood]. Cienc. Florest 14:133-144. In Portuguese with abstract in English.

Marsoem, N., Kikata, Y. (1987) The effect of interlocked grain on the mechanical properties of white meranti. Bull. Nagoya Univ. For. N8 9:51-77.

Mattheck, C., Kubler, H. (1995) Wood. The Internal Optimization of Trees. Springer, Berlin. pp. 68-69.

Muneri, A., Legate, W., Palmer, G. (1999) Relationships between surface growth strain and some tree wood and sawn timber characteristics of Eucalyptus cloeziana. South. Afr. For. J. 187:41-49.

Muneri, A., Knight, J., Legate, W., Palmer, G. (2000) Relationships between surface longitudinal growth strain and tree size, wood properties and timber distortion of 4 year old plantation grown Eucalyptus cloeziana. In: IUFRO Conference -the Future of Eucalypts for Wood Products, 2000, Launceston. 2000. IUFRO Proceedings. p. 292-300.

Okuyama, T., Sasaki, Y., Kikata, Y., Kawai, N. (1981) The seasonal change in growth stress in the tree trunk. Mokuzai Gakkaishi 27:350-355.

Purnell, R.C. (1988) Variation in wood properties of Eucalyptus nitens in a provenance trial on the eastern Transvaal Highveld in South Africa. South. Afr. For. J. 144:10-22.

Raymond, C.A. (2002) Genetics of Eucalyptus wood properties. Ann. Sci. For. 59:525-531.

Rudinsky, J.A., Vite, J.P. (1959) Certain ecological and phylogenetic aspects of the pattern of water conduction in conifers. Forest Sci. 5:259-266.

Santos, P.E.T. (2002) Avaliação de características tecnológicas de madeira para serraria em progênies de polinização aberta de eucalipto e implicações para o melhoramento genético [Evaluation of technological properties of wood in open-pollinated progenies of eucalyptus and its implication for sawn timber breeding program]. Doctoral Dissertation, Luiz de Queiroz College of Agriculture, São Paulo University, Brazil. In Portuguese with abstract in English.
SAS Institute Inc. (2013) SAS software, version 9.4. SAS Institute Inc., Cary, North Carolina.

Schacht, L., Garcia, J.N., Vencovsky, R. (1998) Variação genética de indicadores de tensão de crescimento em clones de Eucalyptus urophylla [Genetic variation of growth stress indicators in clones of Eucalyptus urophylla]. Sci. For. 54:55-68. In Portuguese with abstract in English.

Serpa, P.N., Vital, B.N., Della Lucia, R.M., Pimenta, A.S. (2003) Avaliação de algumas propriedades da madeira de Eucalyptus grandis, Eucalyptus saligna e Pinus elliottii. [Evaluation of some properties of Eucalyptus grandis, Eucalyptus saligna and Pinus elliottii]. Rev. Árvore 27:723-733. In Portuguese with abstract in English.

Silva, B.B., Alvez, J.J.A., Cavalcanti, E.P., Dantas, R.T. (2002) Potencial eólico na dir otencial eólico na direção predominante do $v$ edominante do vento no Norte o no Nordeste brasileiro [Wind energy potential for the prevailing direction in Northeast Brazil]. Rev. Bras. Eng. Agríc. Ambient. 6:431-439.

Skolmen, R.G. (1963). Robusta eucalyptus wood: its properties and uses. USDA, Forest Service, Pacific Southwest Forest and Range Experiment Station, Berkeley, 1963.

Soares, V.C., Bianchi, M.L., Trugilho, P.F., Hofler, J., Pereira, A.J. (2015) Análise das propriedades da madeira e do carvão vegetal de híbridos de eucalipto em três idades [Properties of eucalyptus wood hybrids and charcoal at three ages]. Cerne 21:191-197. In Portuguese with abstract in English.

Tejada, Á., Okuyama, T., Yamamoto, H., Yoshida, M. (1997) Reduction of growth stress in logs by direct heat treatment: assessment of a commercial-scale operation. Forest Prod. J. 47:86-93.

Thinley, C., Palmer, G., Vanclay, J.K., Henson, M. (2005) Spiral and interlocking grain in Eucalyptus dunii. Eur. J. Wood Wood Prod. 63:372-37.

Trevisan, R., Denardi, L., Cardoso, G.V., Haselein, R., Santini, E.J. (2013) Efeito do desbaste nas rachaduras de topo das toras de Eucalyptus grandis W. Hill ex Maiden [Axial variation of the end splits index in the base and top of Eucalyptus grandis W. Hill ex Maiden logs]. Sci. For. 97:75-81. In Portuguese with abstract in English.

Webb, C.D. (1969) Variation of interlocked grain in Sweetgum. Forest Prod. J. 19:45-48.

Weddell, E. (1961) Influence of interlocked grain on the bending strength of timber, with particular reference to utile and greenheart. J. Inst. Wood Sci. 7:56-72.

Wilson, P.J. (1985) Splitting studies on logs of Eucalyptus macarthurii, E. elata and E. radiata. Institute for Commercial Forestry Research Annual Report. pp. 135-142.

Yang, J.L., Fife, D., Matheson, A.C. (2001) Growth strain in three provenances of plantation-grown Eucalyptus globulus Labill. Aust. For. 64:248-256.

Yang, J.L, Bailleres, H., Okuyama, A., Downes, G. (2005) Measurement methods for longitudinal surface strain in trees: a review. Aust. For. 68:34-43. 